\title{
The Impact of Covid-19 on Abrahamic Fundamentalist Groups
}

\author{
Nina Käsehage | ORCID: 0000-0002-2261-8595 \\ Senior Lecturer, Department for Religious Studies and Intercultural \\ Theology, Faculty of Theology, University of Rostock, Rostock, Germany \\ nina.kaesehage@uni-rostock.de
}

\begin{abstract}
This contribution discusses the question whether there is a general interlinking between the fundamentalist perception and practice of Abrahamic religions by some believers or groups and their (in-)ability to cope with pandemics such as Covid-19, or if this assumption is misleading. With the help of selected examples from fundamentalist groups of the Abrahamic religions, it will be shown that some fundamentalist actors see Covid-19 as a divine punishment and make use of the pandemic for radical mobilization of their members, while other religious groups and leaders concentrate on the resilience and healing aspects of their followers during the pandemic. The different responses of coping lead to the question whether monotheistic religions might be more susceptible to fundamentalist reactions to pandemics than other religions.
\end{abstract}

\section{Keywords}

Abrahamic religions - Covid-19 - pandemic - religious fundamentalism - violence

\section{Introduction}

Since 2020, when Covid-19 caused a global health crisis, including an increased death rate, similar reactions towards the pandemic and governmental health strategies could be observed in terms of fundamentalist actors and groups from the Abrahamic religions around the world. In these milieus, Covid-19 was mainly perceived as: 
a) divine punishment for disbelievers or those who had left the 'pure' way of religious practice and sometimes accompanied by the assumption that it is

b) a weapon against the religious (and political) enemies of their own religious peer group.

Governmental health requirements, e.g. vaccinations, and societal restrictions such as lockdowns to contain the pandemic have been understood as an attempt to limit religious freedom and to discriminate against individual religiosity.

These reactions led to the question why certain members and groups of Judaism, Christianity and Islam responded in that specific way towards the pandemic.

Generally speaking, religious affiliation to a religious fundamentalist group cannot be equated with an affinity for conspiracy theories although their perception of certain 'divine' predictions can overlap with these theories, for instance in view of blaming religious or political opponents of being responsible for the pandemic or calling Covid-19 a plot against 'true' believers. ${ }^{1}$ Nevertheless, this interlinking has been used for decades by various scholars and other groups with regard to religious fundamentalist groups. It seems to uncover their individual assumption that faith in a transcendental power is (mainly) used by religions for destructive goals. This assumption itself shows the fundamentalist perspective of the critics regarding religions and is therefore not useful for a scientific approach to the topic. ${ }^{2}$

In order to reorient the discourse on religious fundamentalism to a scientific level, this paper examines possible reasons for the fundamentalist interpretation of monotheistic religions that might be co-responsible for the significant impact of Covid-19 on Abrahamic fundamentalists.

The definition of religious fundamentalism has already been sufficiently explained in the literature. ${ }^{3}$ Therefore, this contribution focusses on a few

1 Cf. Mitrofanova, The Impact of Covid-19 on Orthodox Groups and Believers in Russia, p. 49 et seq.; Malik, Self-Isolation Might Stop Coronavirus, but It Will Speed the Spread of Extremism; Tony Blair Institute for Global Change, How extremist groups are responding to Covid-19, p. 5 .

2 Cf. Berman, Radical, Religious, and Violent; Charles, When Religion Becomes Evil; Lincoln, Holy Terrors; Ward/Sherlock, Religion and Terrorism.

3 Due to the current framework of this contribution, the discussion of the definition of religious fundamentalism and all of its criteria has to be limited to a few indicators. The 
characteristics of religious fundamentalism that are useful for a better understanding related to the misuse of Covid-19 by some Abrahamic fundamentalists. According to Almond et al.,

[...] the fundamentalist's stance toward the world will depend, first, on their assessment of the outside world, and second, on the role they think they are supposed to be playing in the divine plan. But whether they operate in historic time or in messianic time, whether the threatening "world" is the village across the river or the powerful nation-state rival, all fundamentalists expect the enemy to be abolished one way or another, sooner or later. God's world is pure, not pluralistic. ${ }^{4}$

Transposed to the present contribution, fundamentalist Abrahamic adherents and groups believe that Covid-19 and its negative side-effects are part of religious prophecies that have been announced in their Holy Scriptures. These predictions are understood as tests of the faith of their adherents and should serve to divide the 'true' from the 'false' believers. ${ }^{5}$

Despite universal insecurity over the pandemic that led to a spike in spirituality in several 'mainstream' believers of various religions since the outbreak of Covid-19, the fundamentalist representatives of the Abrahamic religions interpreted their way of believing as the only protection against this disease. This self-conception is based on the core elements of religious fundamentalism: a dualistic worldview that divides the world into believers and apostates, a literal observance of the Holy Scriptures and the belief that only the 'true' believers will be saved at the end of all time. ${ }^{6}$ The uniform religious practice of religious fundamentalists is an expression of their longing for 'purity' regarding divine commandments to save their religious identity and to keep alternative views that might question their religious interpretation outside the community. ${ }^{7}$ The health crisis that occurred as a result of Covid-19 is interpreted as a harbinger of the end-of-time. The more negative side effects of this pandemic were reported, the stronger became the fundamentalist conviction that solely their

Fundamentalism Project of Marty and Appleby can be recommended as a standard work in this context (parts of this book series are cited in this paper).

4 Almond et al., Strong Religion, p. 138.

5 Cf. MEMRI, The way forward - A word of advice on the coronavirus pandemic; Estrin, Israel Faces Challenges in Fighting Coronavirus in Ultra-Orthodox Communities; Malato et al., How Faith Shapes Feelings About The Coronavirus Outbreak, p. 10.

6 Cf. Almond et al., Strong Religion, p. 17.

7 Cf. Almond et al., Strong Religion, pp. 17, 218. 
religious interpretation and practice could function as a shield from suffering, illness and death.

\section{Religious Demarcation as a Potential Source of Fundamentalism}

Riesebrodt points out that Judaism, Christianity and Islam have positioned themselves in contrast to other religions and that this process is still an ongoing reference point between them. ${ }^{8}$ In comparison to other religions, all of the three monotheistic religions discussed here tend to use polemics against other religions in order to distinguish themselves from previous major religions of the region and - in the end - from each other. ${ }^{9}$

Starting with Judaism, the God of the Hebrew Bible is invisible and has to be distinguished from the tangible polytheistic gods, their power and the mode of worship. Therefore, the first commandment of the Hebrew Bible calls its God the eternal and distances his religion from others by making the worship of other Gods punishable. ${ }^{10}$

Early Christianity distanced itself from the prevailing Jewry by calling its religious representatives 'false prophets'. After expanding to the Hellenistic world, its demarcation from other religions was expanded towards the pagans who were decried as worshippers of the devil. ${ }^{11}$

After its emergence, early Islam distinguished between monotheistic religions of a higher order such as Jewry and Christianity, and of a minor order such as idolatry or polytheism. Its policy towards polytheism continued the one of Jewry and Christianity in order to prevent the Muslim's relapse into polytheistic worship. In view of Jewry and Christianity, Islam indicates a comparable dimension between its religion and the other bookish religions, but describes itself as the religion that restores the original message. ${ }^{12}$

As a result of their content-related proximity, the mutual demarcation of the Abrahamic religions can be seen as essentially of their own constitution. The following criteria of the three monotheistic religions underline some of their similarities. All of the concerned religions include:

\footnotetext{
8 Cf. Riesebrodt, Cultus und Heilsversprechen, pp. 47-5o.

9 Cf. Riesebrodt, Cultus und Heilsversprechen, p. 5 ०.

10 Cf. Riesebrodt, Cultus und Heilsversprechen, p. 47.

11 Cf. Riesebrodt, Cultus und Heilsversprechen, p. 47 et seq.

12 Cf. Riesebrodt, Cultus und Heilsversprechen, p. 48 et seq.
} 
- a God as the creator of the world

- a monotheistic belief

- the rejection of polytheism and

- (various) penalties for apostates.

In particular, the monotheistic claim of the Abrahamic religions regarding the 'true' God is not only an aspect of mutual demarcation, but often used by fundamentalist Abrahamic actors and groups to legitimize violence towards other religions and believers. ${ }^{13}$ Nevertheless, this attitude also became visible in view of other religions such as Hinduism since Covid-19 occurred. In India, where the major religion is Hinduism, several Hindu believers and groups accused the Muslims - as representatives of a religious minority - of spreading the disease, for instance through collective worship or extensive wedding celebrations. ${ }^{14}$

With respect to other religions, the reactions of believers towards Covid-19 were different. In view of Tibetan Buddhism, Álvarez-Ortega points out that apart from traditional healing methods such as meditation to enhance improved individual well-being, Buddhist authorities recommended proper compliance with official health requirements during the pandemic and the trust of their believers in science. Most significantly, prominent figures such as the Dalai Lama called for interreligious unity and an interreligious consensus related to collaboration to tackle Covid-19. ${ }^{15}$ The compliance of the majority of Buddhist believers with these recommendations differed from the reactions of the fundamentalist followers of the Abrahamic religions, although their mainstream representatives also declared themselves in favour of governmental prevention measures such as vaccination. ${ }^{16}$ While some groups feared that their religious practices, such as for instance the touching or kissing of Holy Books or statues, would be decimated by the lockdowns, others called upon the responsibility of each believer regarding personal safety measures and welcomed the online-celebration of their worship during the pandemic. Most of the religious representatives described their own religious practices and their own transgressive behaviour as important examples or models for their communities in terms of coping with the crisis. ${ }^{17}$

\footnotetext{
13 Opposite findings regarding that theory can be found in Almond et al., Strong Religion, p. 219 .

14 Cf. Slater/Masih, As the World Looks for Coronavirus Scapegoats, Muslims are blamed in India.

15 Cf. Álvarez-Ortega, Global Virus, International Lamas, pp. 189-192.

16 Cf. Bruckmoser, Will Gott geimpfte Gläubige?, p. 9.

17 A reflection regarding the diversity of this discussion may, for instance, be found in IRAS cotis, Wertvoller Beitrag der Religionsgemeinschaften in der Corona-Krise.
} 


\section{Abrahamic Fundamentalist Reactions Related to Covid-19}

In particular, with regard to the Abrahamic religions, fundamentalist reactions to the pandemic were in evidence. A selection of these responses to Covid-19 are discussed in the following. It goes without saying that these fundamentalist actors and groups do not reflect the majority opinion among Abrahamic believers, but only a minority view within this religious spectrum.

\subsection{Jewish Fundamentalism}

According to Ariel, Jewish fundamentalists could be defined

[...] as those taking affirmative religious stands in face of secularization and liberalization of Jewish life: those upholding and strengthening tradition in face of other options in Jewish culture. Jewish fundamentalists insist on the validity and authority of the Jewish sacred scriptures, see special merits in studying the texts as central to Jewish life and identity, and are protective of the narratives the texts offer. Both groups are eschatologically oriented, but while the Zionist-Orthodox believe in taking an active role in history, the ultra-Orthodox have often objected to such attempts. While the ultra-Orthodox take their model from the alter heim, Eastern European Jewish society before Communism, Nazism and emigration brought it to an end, Zionist Orthodox groups have come instead to promote the Land of Israel as a focal point of their political vision. ${ }^{18}$

Although both Jewish fundamentalist groups, the Nationalist and ultraOrthodox, aim to protect Jewish traditions and religious identity, to preserve the Halacha and to follow religious laws as well as rituals, ${ }^{19}$ their reactions towards the pandemic differed. While Zionist Orthodox around the world complied with the health measures that included their religious practices, the compliance of ultra-Orthodox believers towards these measures was more reluctant or hesitant. Due to their strict observance of religious rituals that demands several participants and the initial unwillingness of leading ultraOrthodox rabbis to appeal to their followers to comply with the health requirements and to close religious schools temporarily, the number of sick and dead community members in this group increased. ${ }^{20}$

18 Ariel, Cultural Wars and CommunalPerseverance, p. 26 et seq. Cf. Ingber, Fundamentalismus im Judentum und in der jüdisch-israelischen Gesellschaft im Staat Israel, pp. 91-115.

19 Cf. Ariel, Cultural Wars and Communal Perseverance, p. 40.

20 Cf. Ariel, Cultural Wars and Communal Perseverance, p. 41. 
As a response to this behaviour, liberal and national Orthodox Jewish groups condemned the ultra-Orthodox by calling them 'betrayers' "of the Jewish dictum of putting safety of life above all. Zionist Orthodox clearly cast their vote in the modernist ballot, and felt morally superior to, as well as more sophisticated than the separatist ultra-Orthodox."21

The various reactions of Jewish fundamentalist groups regarding Covid-19 and its governmental prevention measures, ${ }^{22}$ underline the fragmentation of Jewish fundamentalism. Despite various religious commonalities between the ultra-Orthodox and Zionist Orthodox, such as their strict observance of sacred scriptures and their belief "in the arrival of the Messianic times", their interaction with surrounding civil society and their engagement within Israeli politics in order to fulfil their religious goals distinguish both fundamentalist milieus. ${ }^{23}$ Ariel points out that the pandemic divided both groups and forced them to decide whether they wanted to be seen as "a separatist community that has its own norms, sources of authority and priorities; or as a modernist community, part of a larger civic society, abiding by the standards and laws of the land."24 The long-term effects of Covid-19 regarding the internal life of Orthodox Jewish communities and their interactions with non-Orthodox groups will be a challenge in the future. ${ }^{25}$

\subsection{Christian Fundamentalism}

The term fundamentalism first occurred within the anthology The Fundamentals: A Testimony to the Truth that contained 12 books and was edited during 1910 and 1917 in the USA. Initially, the term was used as a positive self-descriptor by Protestants during internal church disputes, but thereafter lead to a split between modernists and traditionalists in religion and society. The establishment of the World's Christian Fundamentalist Association in 1919 can be seen as an alliance of various orthodox Protestant groups. ${ }^{26}$ They articulated the following religious convictions that became known as the five fundamentals: "the absolute inerrancy of the Scripture, the virgin birth, the representative sin

21 Ariel, Cultural Wars and Communal Perseverance, p. 41.

22 Cf. Jones, Top Rabbis: Look at the Signs, Messiah is Coming!; Halbfinger, Virus Soars Among Ultra-Orthodox Jews as Many Flout Israel's Rules; Rabinowitz, In Spite of Regulations, ultraOrthodox Schools Remain Open in Jerusalem COVID-19 Hotspots; Rabinowitz, For Israel's ultra-Orthodox Society, Coronavirus Has Changed the Rules.

23 Ariel, Cultural Wars and Communal Perseverance, p. 42.

24 Ariel, Cultural Wars and Communal Perseverance, p. 42.

25 Cf. Ariel, Cultural Wars and Communal Perseverance, p. 42 et seq.

26 Cf. Kienzler, Der Religiöse Fundamentalismus, p. 17 et seq.; Deen Larsen, Religiöser Fundamentalismus in den USA, p. 70. 
offering, the physical resurrection and the return of Christ in terms of establishing of his millennial reign before the Last Judgement."27 Their claim related to the inspired nature of the Word and the inerrancy of the Bible was directed against the historical-critical exegesis of other ecclesiastical groups and the theory of evolution as the main point of criticism of modernity.

For some fundamentalist Christian believers, Covid-19 was a chastisement for their sins and their devotion to modernity. ${ }^{28}$ Various priests and representatives of orthodox Christian groups called Covid-19 "a pandemic of fear" 29 or "God's punishment for our people." ${ }^{30}$ According to Mitrofanova

Some of the dissidents did not believe in the pandemic at all, considering it a cloak for a global conspiracy; the majority admitted the existence of the virus, but viewed measures taken against it as redundant. Some limited their objections to verbal polemics; some, despite the prohibition, continued public church services. ${ }^{31}$

Even before the ecclesiastical lockdowns, Christian authorities such as Daniil (Dorovskikh), the Metropolitan of Kurgan and Belozerskoe, said:

This thought that we can avoid sickness only hiding in our homes and, vice versa, that it is more likely that we will fall ill after attending the churches is not the thought of the Holy Fathers [...] the coronavirus is the consequence of our sins, God's punishment for our people. It reminds us to trust not in ethanol and other disinfecting solutions, but first of all in God. ${ }^{32}$

In particular with regard to those countries where the Christian religion and worship were forbidden officially and believers had been blamed for the spread of diseases in earlier times, governmental health restrictions regarding Covid19 reminded "corona-dissidents" of "closing churches by the Soviet government

27 Kienzler, Der Religiöse Fundamentalismus, p. 30, cited and translated by Käsehage in Religious Fundamentalism in the Age of Pandemic, Introduction, p. 13.

28 Cf. The John-Henry Westen Show, 'It's About Sin!' Hermit says coronavirus is a 'chastisement'.

29 Selinov cited by Mitrofanova, The Impact of Covid-19 on Orthodox Groups and Believers in Russia, p. 57 .

30 Tyurenkov/Metropolitan cited by Mitrofanova, The Impact of Covid-19 on Orthodox Groups and Believers in Russia, p. 57.

31 Mitrofanova, The Impact of Covid-19 on Orthodox Groups and Believers in Russia, p. 57.

32 Tyurenkov/Metropolitan cited by Mitrofanova, The Impact of Covid-19 on Orthodox Groups and Believers in Russia, p. 57. 
in the period of persecutions." 33 This explains their strong resistance towards official health measures that were supposed to save lives but triggered past traumas and present fears in some Christian believers related to their freedom of religion. Therefore, it can be stated that the disease Covid-19 and the related governmental prevention measures functioned as a cipher for suppression of individual faith for some fundamentalist Christian actors and groups.

The idea of being vaccinated has always been a sensitive topic within fundamentalist or orthodox ${ }^{34}$ Christian milieus in other contexts, for instance, regarding children's diseases such as mumps or measles. Predominantly, the decision for or against the vaccination of their children was based on religious arguments for orthodox Protestant parents while "[m]edical arguments thus appeared to be of minor importance among orthodox Protestant parents." ${ }^{35}$ Transposed to the present vaccination situation related to Covid-19, liberal Christian representatives agree on the need to comply with this health recommendation, ${ }^{36}$ but fundamentalist Christian actors and groups raised their voices against the vaccination. ${ }^{37}$ For them, the pandemic is a test for 'true' believers by the almighty God and if he wants them to survive they will survive without any medical support. Those believers who will suffer in silence will be blessed by God while the others, who will trust in scientific explanations regarding the origin of the illnesses and a medical cure for it, are seen as apostates. If believers died of Covid-19, this would be interpreted as divine intervention in order to bring them back into God's fold.

Interestingly, Covid-19 uncovered past connections between nationalists and evangelical groups within the USA that can be observed again in terms of their mutual resistance towards the trust in the' origin of the pandemic and the relevant governmental health restrictions. The early evangelical communities combined their claim for America as the 'new' Israel and God's chosen country with their aim of a Christian nation with a Christian morality and their fight

33 Mitrofanova, The Impact of Covid-19 on Orthodox Groups and Believers in Russia, p. 6o.

34 In this contribution, the terms 'fundamentalist' and 'orthodox' are used synonymously.

35 Cf. Ruijs, Acceptance of Vaccination among Orthodox Protestants in The Netherlands, p. 75. Chapters four and six are of specific interest in terms of the present contribution, because they deal with the process of decision-making of orthodox Protestant parents in terms of the vaccination of their children and the impact of religious leaders on that process.

36 Cf. Bruckmoser, Will Gott geimpfte Gläubige?, p. 9.

37 "Media Matters for America, a liberal media watchdog, found posts within U.S. Facebook groups claiming the pandemic is an effort to force people into accepting vaccines and, perhaps, even a surreptitious plot to inject people with microchips. Similar messages appeared in WhatsApp messages shared widely in Italy, which has a long-standing antivaxxer community, while groups in France have called for a boycott of any governmentbacked coronavirus vaccine program": Scott/Overly, Conspiracy Theorists, Far-right Extremists Around the World Seize on the Pandemic. 
against modernity as the enemy of 'pure' Christianity. ${ }^{38}$ Individuals who did not share that conviction have been rejected as true Christians and Americans by these evangelical groups. ${ }^{39}$ Therefore, their main goal was the conversion and salvation of 'lost souls' through the announcement of the second coming of Jesus Christ and revivalism. ${ }^{40}$ With regard to the tendency of many scholars to equate Fundamentalism with Evangelicalism, it is important to follow Riesebrodt's explanation that the pre-millenarian expectation of catastrophes that characterises Fundamentalism differs from post-millennialism that defines the typical American tradition of Evangelicalism. ${ }^{41}$

Some of the white supremacy opponents of the US health restrictions who deny the existence of corona can be found in the field of Evangelical interpretation of Christianity. ${ }^{42}$ The following two examples of the right-wing platform ${ }_{4}$ Chan visualize this ideological interlinking:

1) "Corona is a biblical term (Corona spinea crown of thorns). It is a punishment for sins." 43

2) "Corona is a punishment from god. We deserve it for turning our backs on god. LGBT propaganda in schools, abortions, drag queens [...]"44

According to Wilson, "[a]pocalyptic narratives - whether of societal collapse, biblical rapture, or race war - are the central way that the spectrum of farright movements draw in followers and resources." ${ }^{25}$ Covid-19 provides an opportunity for the far right movements to interlink its appearance with the need of survivalist strategies in order to win further adherents. Charismatic leaders such as "James Wesley Rawles, the reclusive founder of the separatist and survivalist American Redoubt movement" who functions as well "as the ideological godfather of a movement which promotes 'political migration' by rightwing Christians to the interior of the Pacific north-west"46 is one among many examples of the revitalization of the alliance between right-wing and evangelical groups that have been observed in view of US-American history and politics. This development could be interpreted as closing the circle of the

38 Cf. Riesebrodt, Protestantischer Fundamentalismus in den USA, p. 13.

39 Schäfer, Kampf der Fundamentalismen, pp. 90, 100 et seq., 108.

40 Kienzler, Der Religiöse Fundamentalismus, p. 25 et seq.

41 Cf. Riesebrodt, Protestantischer Fundamentalismus in den USA, p. 10.

42 Cf. Gartenstein-Ross et al., The Growing Threat posed by Accelerationist Groups Worldwide.

43 4Chan cited by Koblentz-Stenzler, The Far-Right Leverages COVID-19 Pandemic to Gain Influence and Encourage Violence, p. 8.

44 4Chan cited by Koblentz-Stenzler, The Far-Right Leverages COVID-19 Pandemic to Gain Influence and Encourage Violence, p. 9.

45 Wilson, Disinformation and Blame: How America's Far Right is Capitalizing on Coronavirus.

46 Wilson, Disinformation and Blame: How America's Far Right is Capitalizing on Coronavirus. 
past roots for some right-wing orientated Christian fundamentalists with its modern representatives. ${ }^{47}$

\subsection{Islamic Fundamentalism}

Islamic fundamentalism may be defined by a few criteria that seem to fit most of its manifestations. It contains:

1) a specific selection of religious-historical incidents and the rejection of those events that do not fit into their religious interpretation,

2) absolutization of Islam regarding all areas of life,

3) sovereignty of God and his divine law over man-made governments and laws,

4) the existence of differently expressed anti-Semitism and

5) a biologistic human interpretation or image, homophobia and specific expectations related to gender roles and gender hierarchy. ${ }^{48}$

Three major motives regarding the pandemic are used by Islamic fundamentalist groups: Covid-19 is "a divine punishment for the 'Crusader enemies of Islam', ${ }^{49}$ a warning for 'true' Muslims to turn back to the fundamentalist interpretation of Islam and a useful weapon against their religious and political enemies.

With regard to the last aspect, Al-Qaeda (AQ) and the Islamic State (IS) postulated that Covid-19 is a 'soldier of Allah' and very useful to weaken the 'Western enemy' economically. They tried to take advantage of the pandemic by attacking the Western societies that have been deeply impacted by the pandemic with the help of all 'true' believers as the following quote of AQ illustrates:

Everything that was once taken for granted lies now in grave jeopardy. Economies of major nations lie in ruin as they find their entire state apparatus, including army and security, pinned down by an invisible enemy. Norms of social behavior, lifestyles, everything is being redefined. ${ }^{50}$

47 Cf. Riesebrodt, Protestantischer Fundamentalismus in den USA, p. 11.

48 Cf. Seidensticker, Islamismus, Geschichte, Vordenker, Organisationen, pp. 9-14. In opposition to Seidensticker, I reject the use of the term Islamism as it interlinks the entire religion Islam with a radical Islamic minority and leads to a misperception of Islam in public and furthermore to discrimination against its members: Cf. Käsehage, Die gegenwärtige salafistische Szene in Deutschland, p. 62 et seq.

49 Tony Blair Institute for Global Change, How extremist groups are responding to Covid-19, p. 3 .

50 Memri, The Way Forward - A Word of Advice on the Coronavirus Pandemic. 
Against that background, Is-linked Ribat Media posted the following picture, saying Covid “destroys the crusaders' economy."51

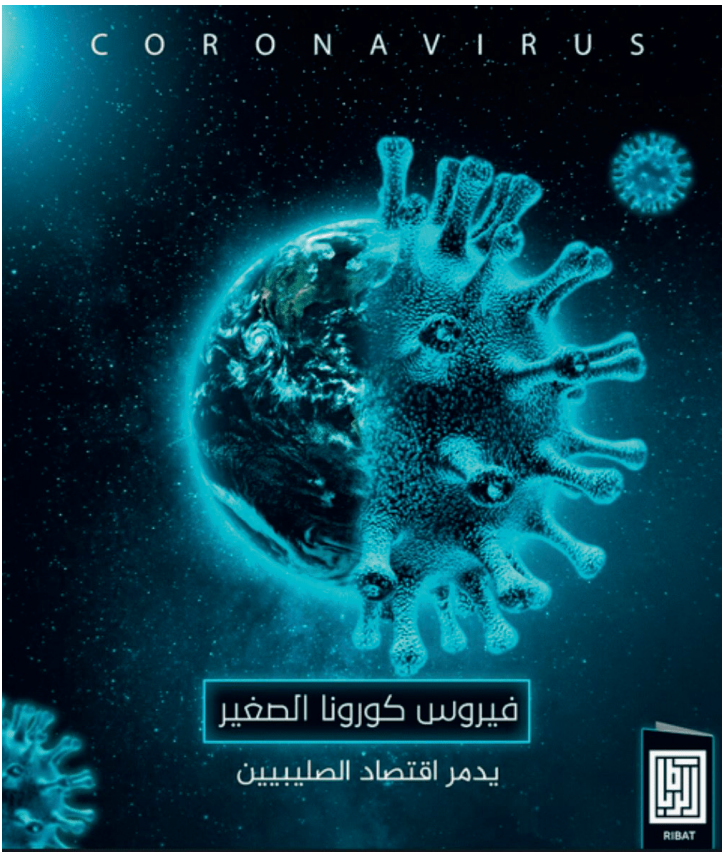

FIGURE 1

How Terrorists Are Trying to Make Coronavirus More Friend Than Foe, Homeland Security Today, 14.04.2020, https://www.hstoday.us/ subject-matter-areas/counterterrorism/how-terrorists-aretrying-to-make-coronavirusmore-friend-than-foe/ (date of last access: 22.05.2O2O) SOURCE: RIBAT MEDIA CITED FROM JOHNSON

The exploitation of the economic crisis of Western civilizations by both AQ and Is highlighted two aspects: the ongoing sense of relative powerlessness of both jihadist movements vis-à-vis Western hegemony and their objective of gaining adherents for a war of revenge against their self-constructed enemies. In this context, Is called on its followers to make use of the crisis by engaging in the global jihad and asked them to commit terrorist attacks while the security services were particularly overloaded with pandemic-related measures. ${ }^{52}$ As a religious legitimation for the participation in militant jihad, it was defined as the most beloved obedience to God that would prevent believers from falling ill with his plague (Covid) that was sent from above to torture the infidels.

Another task of AQ related to the pandemic was the increase of conversions to Islam during the social lockdowns. In order to gain more followers via

$5^{1} \quad$ Ribat Media cited from Johnson, How Terrorists Are Trying to Make Coronavirus More Friend Than Foe.

52 Cf. Coleman, The Impact of Coronavirus on Terrorism in the Sahel. 
social media, the fundamentalist Islamic group blamed Covid-19 as a 'Western' instrument that suppresses Muslims universally. ${ }^{53}$

Additional fundamentalist strategies related to the exploitation of the pandemic included fatwas from members of the Muslim Brotherhood or some well-known Salafists.

The Global Fatwa Index (GFI), subordinate to Egypt's Dar Al-Ifta, [...] stresses that the [epidemic] is being exploited by two elements. The first of these elements is the extremist and terrorist organizations, which use it to implement some of their ideas ... in order to spread chaos, fear, hysteria and mistrust of the homeland's [official] institutions and leaders. The second [element that is] exploiting the spread of the virus is vile [speculators] who try to monopolize [the market] for medicines and medical equipment that help to protect against this virus [...] or hoard foodstuffs [...] so as to raise their prices. They do this even though Islam forbids speculation $[\ldots]^{54}$

The following fatwas exemplify how the fundamentalist Islamic actors and groups tried to make use of the pandemic:

1) Salafist clerics such as the Mauritanian Sheikh Yahthia Ould Dah recommended the buying of sharia amulets that would function as a protection against Covid-19: "the cost of the treatment for this disease would vary according to [the identity] of the patient, his circumstances and his (financial) means." 55

2) The occurrence of Covid-19 was interlinked with the Egyptian ban of fullface veils in public institutions and universities and called for a divine penalty for this governmental decision in order to mobilize resistance towards this political decision. ${ }^{56}$

3) The Muslim Brotherhood member Wagdi Ghneim named Covid-19 "Allah's revenge on China and a trial and test for the Muslims, 'and Salafist

53 Cf. Coleman, The Impact of Coronavirus on Terrorism in the Sahel.

54 MEMri, Egypt's Official Fatwa-issuing Body Published a Report on Fatwas Religious Ruling Issued Across the Muslim World Regarding the Coronavirus Pandemic.

55 MEMri, Egypt's Official Fatwa-issuing Body Published a Report on Fatwas Religious Ruling Issued Across the Muslim World Regarding the Coronavirus Pandemic.

56 Cf. memri, Egypt's Official Fatwa-issuing Body Published a Report on Fatwas Religious Ruling Issued Across the Muslim World Regarding the Coronavirus Pandemic. 
Yasser Burhami [said] that the virus is divine punishment for the crisis of the Uyghurs.'"57

The selected examples of fundamentalist Islamic reactions regarding the pandemic included contradictory messages in terms of Covid-19 and visualized that the virus was misused by Islamic fundamentalist groups as a means to an end for their own purposes: to gain power over both their adherents and their enemies and to increase their sphere of influence in terms of Islam.

\section{5}

\section{Conclusion}

As a result of the pandemic, a lot of 'secular' Jews, Christians and Muslims re-discovered their faith as a source of hope and protection against the invisible enemy. The tendency to turn to a transcendent power in the search for help has been observed through every historical crisis when war and pandemics increased in frequency or reach and resulted in thousands of victims. According to Riesebrodt, new dimensions of powerlessness and risks have become a source for the formation of new religious groups and movements. As far as Western modernity could impart authentically the faith in its ability to increase control towards nature, the human body and the social order, religion was in decline. As a result of the partial collapse related to their faith, religious forms of prevention and coping in crisis appeared to a larger extent. With respect to that development, secularization and revitalization of religion indicate no contradiction, but the two sides of a social transformation process. ${ }^{58}$ This 'new-born' faith in the face of a worldwide crisis reflects the contemporary status of 'mainstream' believers to cope with crises: as soon as the crisis is over, the demand for spiritual support appears to decrease.

In view of fundamentalist movements, Riesebrodt suggests analyses from the theoretical perspective of religious crisis research and to consider their occurrence in view of the social causes and cultural achievements. ${ }^{59}$ With reference to the discussed fundamentalist reactions of Abrahamic religions towards the pandemic, it can be stated that some believers are financially insecure and most of them live constantly isolated from mainstream society, ring-fenced by end-time expectations that have been predicted in their Holy

57 MEMri, Egypt's Official Fatwa-issuing Body Published a Report on Fatwas Religious Ruling Issued Across the Muslim World Regarding the Coronavirus Pandemic.

$5^{8}$ Riesebrodt, Die Rückkehr der Religionen, p. $5^{\circ}$.

59 Riesebrodt, Die Rückkehr der Religionen, p. 51. 
Scriptures. Therefore, fear towards the evil is their daily companion and their faith in a transcendent power their 'only' hope to be protected or 'saved'.

Additionally, it may be stated, that there is an affinity on the part of some members of Abrahamic fundamentalist groups to take advantage of Covid-19 in terms of the realization of their religious purposes. The interlinking between fundamentalist interpretations of the Holy Scriptures of the concerned monotheistic religions and their understanding of the pandemic as a divine 'sign' result from their belief in religious forecasting and their will to trust in an intelligent design of the world where nothing happens without a reason, and only under control by God. This way of thinking includes the possibility to direct the responsibility for man-made incidents to the unknown, unspeakable and inapprehensible. It underlines a tendency of the fundamentalist actors of the Abrahamic religions to search for a strong leadership and guidelines for their lives and unmasks the inability of some individuals to adopt individual responsibility for their own actions. This nature of some fundamentalist actors of Abrahamic religions welcomes the monotheistic archetype of a God creator, a figure who takes the lead. Therefore, this fundamentalist approach to religion is apparently very attractive for believers who like to follow the herd instead of taking the initiative themselves. This specific compilation of some fundamentalist members of Abrahamic religions could be seen as a blessing and a curse at the same time: a blessing when it comes to the development of great momentum for instance in view of appeal for donations for starvelings, but a curse if an ostensibly invisible 'enemy' such as Covid-19 occurs. Particularly in these moments, the fundamentalist representatives of the Abrahamic religions seem to want to get rid of their individual responsibility towards the health challenges that accompany the pandemic and try to transfer it to more readily understood force majeure. This behaviour could lead to serious issues in times of pandemics, not only with regard to Covid-19 but also in view of future pandemics. It seems not only easier to blame others for being apostates and therefore to come to the conclusion that they have 'deserved' this illness as a result of their nonconformist religious practices, but additionally for some religious actors to make use of Covid with respect to the destruction of their (religious) enemies. In that sense, Covid-19 is essential for both, the Abrahamic fundamentalist believers and their role models, charismatic religious leaders such as fundamentalist rabbis, preachers or imams, who explain the pandemic with the help of pre-selected religious sources that give the disease a divine 'sense', 'visualize' the unknown danger and impart the believers a vent for their frustration, anger and fears that are caused by the new virus.

As aforementioned, another similarity between the fundamentalist or orthodox Abrahamic groups regarding the pandemic is their common objective to 
blame the origin of Covid-19 on political or religious 'enemies' and to let its appearance look like a plot against the 'true' religion in order to fuel hatred against these groups and to inspire or enlist their members to violent attacks against the 'others'. This interlinking of political and religious fundamentalist aims related to the pandemic could also be interpreted as a sign for the disentanglement of the origins of religious fundamentalism by some Abrahamic fundamentalists. According to Riesebrodt, religious fundamentalist movements try to gain political power only temporarily in order to establish their religious ideals, but are not basically interested in violence or subversion. Their political activism may be seen as opportunism for a short period of time and as a means to an end. After they have achieved their goals, they might well drop violence and turn to pacifism and quietism once more, and try to establish specific religious ethics and pious lifestyles for their adherents in order to attain their religious salvation. ${ }^{60}$ Seen from this angle, the ongoing postulate of violence as an appropriate means for their followers related to political goals of some Abrahamic fundamentalist groups indicates the need for a further terminological and methodological distinction between the violent or extremist Abrahamic fundamentalists and the religious Abrahamic fundamentalists. The appearance of Covid-19 and the different Abrahamic fundamentalist reactions towards this disease visualized and delineated an important dissimilarity between both fundamentalist groups. Their development should be subjected to careful scientific scrutiny in view of future pandemics for a better categorization and determination of religious fundamentalist reactions from the field of Abrahamic religions and beyond with regard to 'unknown' diseases.

\section{Biography}

Nina Käsehage is an Historian and Religious Scholar. Since 2017, she is a Senior Lecturer at the Department for Religious Studies and Intercultural Theology at the University of Rostock.

Käsehage's major research interests include Islamic Radicalization, New Religious Movements, Qualitative Religious Research, Religious Fundamentalism and the Psychology of Religion.

She is the author of the first basic research on German Salafism 'Die gegenwärtige salafistische Szene in Deutschland - Prediger und Anhänger' (2018), the co-editor of the anthology 'Militant Islam' vs. 'Islamic Militancy', Religion, Violence, Category Formation and Applied Research. 'Contested Fields

6o Riesebrodt, Die Rückkehr der Religionen, p. 55 . 
in the Discourses of Scholarship' (2020, co-author Klaus Hock) and the editor of the international anthology 'Religious Fundamentalism in the Age of Pandemic' (2021).

\section{Bibliography}

Almond, Gabriel A./Appleby, R. Scott/Sivan, Emmanuel: Strong Religion. The Rise of Fundamentalisms around the World. Chicago, IL \& London: The University of Chicago Press 2004.

Berman, Eli:Radical, Religious, and Violent:The New Economics of Terrorism. Cambridge: MIT Press 2009.

Bruckmoser, Josef: Will Gott geimpfte Gläubige? Ist Impfen eine Gewissenspflicht für religiöse Menschen? Vertreter der großen Glaubensgemeinschaften geben differenzierte Antworten auf eine provokante Frage, Salzburger Nachrichten, Geist \& Welt. 30.01.2021, p. 9 .

Coleman, Julie: The Impact of Coronavirus on Terrorism in the Sahel, ICCT, 16.04.2020, https://icct.nl/publication/the-impact-of-coronavirus-on-terrorism-in-the-sahel/ (date of last access: 27.04.2020).

Deen Larsen, Max: Religiöser Fundamentalismus in den USA. In: Clemens Six/Martin Riesebrodt/Siegfried Haas (eds.): Religiöser Fundamentalismus. Vom Kolonialismus zur Globalisierung. Innsbruck \& Wien: Studien Verlag 2004, S. 69-9o.

Estrin, Daniel: Israel Faces Challenges in Fighting Coronavirus in Ultra-Orthodox Communities, NPR, 01.04.2020, https:/www.npr.org/2020/04/o1/825260941/israel -faces-challenges-in-fighting-coronavirus-in-ultra-orthodox-communities?t $=1627385910662$ (date of last access: 01.04.2020).

Gartenstein-Ross, Daveed/Hodgson, Samuel/Clarke, Colin P.: The Growing Threat Posed by Accelerationist Groups Worldwide, fpri, April 2020, https://www.fpri.org/ article/2020/04/the-growing-threat-posed-by-accelerationism-and-accelerationist -groups-worldwide/ (last date of access: 04.05.2020).

Halbfinger, David. M.: Virus Soars Among Ultra-Orthodox Jews as Many Flout Israel's Rules, New York Times, 30.03.2020, https://www.nytimes.com/2020/o3/30/world/ middleeast/coronavirus-israel-cases-orthodox.html (date of last access: 01.04.2020).

Ingber, Michael: Fundamentalismus im Judentum und in der jüdisch-israelischen Gesellschaft im Staat Israel. In: Clemens Six/Siegried Haas/Martin Riesebrodt (eds.): Religiöser Fundamentalismus. Von Kolonialismus zur Globalisierung. Innsbruck \& Wien: Studien Verlag 2005, pp. 91-115.

IRAS COTIS: Wertvoller Beitrag der Religionsgemeinschaften in der Corona-Krise, Zürich, 04.05.2020, pp. 1-2, https://www.iras-cotis.ch/2020/05/04/wertvoller-beitrag-der -religionsgemeinschaften-in-der-corona-krise/ (date of last access: 27.07.2021). 
Jones, Ryan: Top Rabbis: Look at the Signs, Messiah is Coming! Israel Today, 03.08.2020, https://www.israeltoday.co.il/read/top-rabbis-look-at-the-signs-messiah-is-coming/ (date of last access: 27.08.2021).

Käsehage, Nina: Die gegenwärtige salafistische Szene in Deutschland - Prediger und Anhänger. Religionswissenschaft: Forschung und Wissenschaft, 2nd ed. Berlin: LIT 2018.

Kienzler, Klaus: Der Religiöse Fundamentalismus. Christentum, Judentum, Islam, $5^{\text {th }}$ ed. München: C.H. Beck 2007.

Kimball, Charles: When Religion Becomes Evil. Five Warning Signs. New York: Harper One 2008.

Koblentz-Stenzler, Liram: The Far-Right Leverages COVID-19 Pandemic to Gain Influence and Encourage Violence. International Institute for Counter-Terrorism (ICT) April 2020, pp. 1-15.

Lincoln, Bruce: Holy Terrors: Thinking About Religion After September 11, 2nd ed. Chicago, IL \& London: The University of Chicago Press 2006.

Malato, Dan et al.: How Faith Shapes Feelings About The Coronavirus Outbreak. Chicago, IL: University of Chicago Divinity School \& The Associated Press-Norc Center For Public Affairs Research (eds.), May 2020, pp.1-17, https://apnorc.org/wp-content/ uploads/2020/06/Divinity_COVID_report_final.pdf (date of last access: 27.08.2021).

Malik, Nikita: Self-Isolation Might Stop Coronavirus, but It Will Speed the Spread of Extremism, Foreign Policy. 26.03.2020, https://foreignpolicy.com/2020/o3/26/ self-isolation-might-stop-coronavirus-but-spread-extremism/ (date of last access: 31.03.2020).

MEMRI: Egypt's official fatwa issuing body published a report on fatwas religious ruling, issued across the Muslim world regarding the coronavirus pandemic. Egypt Special Dispatch No. 8718, 27.04.2020, https://www.memri.org/reports/egypt\%E2

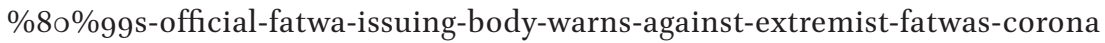
virus-calls-follow (date of last access: 28.04.2020).

MEMRI: The way forward - A word of advice on the coronavirus pandemic. In: AlQaeda Central (ed.): COVID-19 Is Divine Punishment For Sins Of Mankind; Muslims Must Repent, West Must Embrace Islam. 31.03.2020, https://www.memri.org/reports/ al-qaeda-central-covid-19-divine-punishment-sins-mankind-muslims-must-repent -west-must (date of last access: 12.08.2021).

Rabinowitz, Aaron: In Spite of Regulations, ultra-Orthodox Schools Remain Open in Jerusalem COVID-19 Hotspots, Haaretz, 23.12.2020, https://www.haaretz.com/israel -news/.premium-in-spite-of-regulations-ultra-orthodox-schools-remain-open-in -jerusalem-covid-19-hotspots-1.9396746 (date of last access: 12.08.2021).

Rabinowitz, Aaron: For Israel's ultra-Orthodox Society, Coronavirus Has Changed the Rules, Haaretz, 23.09.2020, https:/www.haaretz.com/israel-news/.premium 
.MAGAZINE-for-israel-s-ultra-orthodox-society-coronavirs-has-changed-the -rules-1.9178910 (date of last access: 12.08.2021).

Ribat Media, cited from Bridget Johnson: How Terrorists Are Trying to Make Coronavirus More Friend Than Foe, Homeland Security Today, 14.04.2020, https://www.hstoday .us/subject-matter-areas/counterterrorism/how-terrorists-are-trying-to-make-corona virus-more-friend-than-foe/ (date of last access: 22.05.2020).

Riesebrodt, Martin: Cultus und Heilsversprechen. Eine Theorie der Religionen. München: C.H. Beck 2007.

Riesebrodt, Martin: Die Rückkehr der Religionen. Fundamentalismus und der ,Kampf der Kulturen', 2nd ed. München: Beck Verlag 2001.

Riesebrodt, Martin: Fundamentalismus, Säkularisierng und die Risiken der Moderne. In: Heiner Bielefeldt/Wilhelm Heitmeyer (eds.): Politisierte Religion. Ursachen und Erscheinungsform des modernen Fundamentalismus. Frankfurt am Main: Suhrkamp 1998, pp. 67-9o.

Riesebrodt, Martin: Protestantischer Fundamentalismus in den USA. Die religiösen Rechte im Zeitalter der elektronischen Medien, Evangelische Zentralstelle für Weltanschauungsfragen (ed.), Information Nr. 102, Stuttgart VIII, 1987, pp. 1-24.

Ruijs, Wilhelmina Lamberta Maria: Acceptance of Vaccination among Orthodox Protestants in The Netherlands. Radboud University Nijmegen: Ipskamp Drukkers 2012.

Schäfer, Heinrich Wilhelm: Kampf der Fundamentalismen. Radikales Christentum, radikaler Islam und Europas Moderne. Frankfurt a.M./Leipzig: Verlag der Weltreligionen 2008.

Scott, Mark/Overly, Steven: Conspiracy theorists, far-right extremists around the world seize on the pandemic, Politico, 12.05.2020, https://www-politico-com.cdn.amppro ject.org/c/s/www.politico.com/amp/news/2020/05/12/trans-atlantic-conspiracy -coronavirus-251325 (date of last access: 14.05.2020).

Seidensticker, Tilman: Islamismus, Geschichte, Vordenker, Organisationen. München: C.H. Beck 2014.

Slater, Joanna/Masih, Niha: As the world looks for coronavirus scapegoats, Muslims are blamed in India, The Washington Post, 23.04.2020, https://www.washingtonpost .com/world/asia_pacific/as-world-looks-forcoronavirus-scapegoats-india-pins -blame-on-muslims/2020/04/22/3cb43430-7f3f-11ea-84c2-0792d8591911_story.html (date of last access: 9.08.2020).

The John-Henry Westen Show: 'It's About Sin!' Hermit says coronavirus is a 'chastisement', YouTube, 24.03.2020, https://www.youtube.com/watch?v=PuUTo6MHBIY (date of last access: 28.04.2020).

Tony Blair Institute for Global Change: Snapshot: How extremist groups are responding to Covid-19, 11.06.2020, pp. 1-10. 
Ward, Veronica/Sherlock, Richard: Religion and terrorism: the use of violence in Abrahamic monotheism. Lanham, MA: Lexington Books 2014.

Wilson, Jason: Disinformation and blame: how America's far right is capitalizing on coronavirus, The Guardian, 19.03.2020, https:/www.theguardian.com/world/ 2020/mar/19/america-far-right-coronavirus-outbreak-trump-alex-jones (date of last access: 26.03.2020).

\section{Edited Volume with More Than One Contribution Cited}

Álvarez-Ortega, Miguel: Global Virus, International Lamas: Tibetan Religious Leaders in the Face of the Covid-19 Crisis. In: Nina Käsehage (ed.): Religious Fundamentalism in the Age of Pandemic. Münster: Transcript 2021, pp. 197-220.

Ariel, Yaakov: Cultural Wars and Communal Perseverance: Jewish Fundamentalism in Our Time. In: Nina Käsehage (ed.): Religious Fundamentalism in the Age of Pandemic. Münster: Transcript 2021, pp. 25-45.

Käsehage, Nina: Introduction. In: Nina Käsehage (ed.): Religious Fundamentalism in the Age of Pandemic. Münster: Transcript 2021, pp. 7-24.

Mitrofanova, Anastasia V.: The Impact of Covid-19 on Orthodox Groups and Believers in Russia. In: Nina Käsehage (ed.): Religious Fundamentalism in the Age of Pandemic. Münster: Transcript 2021, pp. 48-8o. 